\title{
PENINGKATAN HASIL BELAJAR IPADENGAN PENDEKATAN SAINTIFIK PADA SISWAKELAS V SD NEGERI 164522 TEBING TINGGI
}

\author{
Nursia Sitorus \\ Surel:nursia.sitorus09@gmail.com
}

\begin{abstract}
The aim of this research is to improve learning result on science subject through scientific approach. This classroom action researchconducted by 2 cycles of the four phases: planning, implementation, observation, reflection. The subjects of this researchwere students from gradeV, SDN 164522 Tebing Tinggi which amounted to 35 students. This research used a qualitative descriptive analysis technique. Based on data obtained from the measurement of the student learning outcomes on the cycle I was80\% and cycle II amounted to 88,57 \%. It means that learning the science using scientific approachcan improve learning outcomes in gradeV SDN 164522 Tebing Tinggi.
\end{abstract}

Keywords : Scientific, Sciences, Qualitative Descriptive Analysis Technique.

\begin{abstract}
ABSTRAK
Penelitian ini bertujuan untuk meningkatkan hasil belajar siswa mata pelajaran IPA melalui pendekatan saintifik. Penelitian tindakan kelas ini dilaksanakan sebanyak 2 siklus dengan empat tahapan yaitu: perencanaan, pelaksanaan, observasi, refleksi. Subjek penelitian ini adalah siswa kelas V SD Negeri 164522 Tebing Tinggi sebanyak 35 siswa. Penelitian ini menggunakan teknik analisis dekriptif kualitatif. Berdasarkan data yang diperoleh dari pengukuran berupa ketuntasan belajar pada siklus I sebesar $80 \%$ dan siklus II sebesar $88,57 \%$. Hal ini berarti pembelajaran IPAdengan menggunakan pendekatan saintifik dapat meningkatkan hasil belajar siswa kelas V SD Negeri 164522 Tebing Tinggi.
\end{abstract}

Kata Kunci : Saintifik, IPA, Teknik Analisis Deskriptive Kualitatif.

\section{PENDAHULUAN}

Pembelajaran adalah suatu proses membelajarkan subjek didik/ pembelajaran yang direncanakan, dilaksanakan, dan dievaluasi secara sistematis agar subjek didik dapat mencapai tujuan pembelajaran secara efektif dan efisien (Depdiknas, 2006). Untuk mencapai tujuanpendidikan, proses pembelajaran harus sepenuhnya diarahkan pada pengembangan ketiga ranah tersebut secara utuh atau holistik, yaitu bahwa pengembangan ranah yang satu tidak bisa dipisahkan dengan ranah lainnya. Hal ini diharapkan dapat melahirkan kualitas pribadi yang mencerminkan keutuhan penguasaan sikap, pengetahuan.

IPA adalah pengetahuan manusia tentang alam yang diperoleh alam dengancara yang terkontrol (Muslichah, 2006). Pembelajaran IPA merupakan proses membelajarkan subjek didik 
dalammempelajari peristiwa yang terjadi di alam ini melalui serangkaian proses ilmiah sehingga tercapai tujuan pembelajaran yang sudah ditetapkan. Berdasarkan pengertian di atas maka dapat disimpulkan bahwa pembelajaran IPA adalah membelajarkan siswa untuk memahami hakikat IPA (proses dan produk serta aplikasinya) mengembangkan sikap ingin tahu, keteguhan hati, ketekunan dan sadar akan nilai-nilai yang ada di dalam masyarakat serta pengembangan ke arah sikap yang positif.

Belajar merupakan suatu proses perubahan yaitu perubahan tingkah laku sebagai hasil dari interaksi dengan lingkungannya dalam menentukan kebutuhan hidupnya. Perubahan-perubahan tersebut akan nyata dalam seluruh aspek tingkah laku(Slameto, 2010).Kegiatan belajar akan aktif apabila peserta didik melakukan kegiatan belajar yang harus dilakukan. Dalam kegiatan pembelajaran sebaiknya siswa diberi kesempatan untuk berdiskusi dan berpendapat.

Menurut

Silbermen,"tanpa peluang untuk mendiskusikan, mengajukan pertanyaan, mempraktikkan, dan mengajarkan kepada siswa lain, proses belajar yang sesungguhnya tidak akan terjadi (Silbermen, 2006). Hal ini dimaksudkan untuk menjaga perhatian siswa selama proses belajar terjadi.

Hasil observasi terhadap guru, siswa, dan media atau alat pembelajaran. Selain itu, juga diperoleh dari hasil wawancara dan catatan lapangan. Berdasarkan refleksi awal ditemui data sebagai berikut. Kenyataannya dari hasil belajar dan observasi di SD Negeri 164522 Tebing Tinggi masih rendah. Hasil belajar siswa yang tuntas belajar pada pretest yang dilakukan hanya 23 siswa $(65,71 \%)$ dan 12siswa belum tuntas belajar $(34,29 \%)$, dengan nilai rata-rata siswa 68,5 padahal KKM yang diberikan adalah 70 . Hal ini berarti beberapa siswa masih ada yang nilai kognitifnya dibawah KKM.

Untuk meningkatkan mutupendidikan dan pengajaran salahsatunya adalah dengan memilih strategiatau cara dalam menyampaikan materi pelajaran agar diperoleh peningkatan hasil belajar siswa khususnya pelajaran IPA.Salah satu metode pembelajaran yang dapat diterapkan adalah pendekatan saintifik. Pendeketan adalah konsep dasar yang mewadahi, menginspirasi, menguatan, dan melatari pemikiran tentang metode pembelajaran diterapkan berdasarkan teori tertentu (Hamruni, 2012). Pendekatan saintifik dimaksudkan untuk memberikan pemahaman kepada peserta didik dalam mengenal, memahami berbagai materi menggunakan pendekatan ilmiah, bahwa informasi bisa berasal dari mana saja, kapan saja, tidak tergantung pada informasi searah dari guru.

Menurut Hosnan (2014) pendekatan saintifik adalah proses pembelajaran yang dirancang 
sedemikian rupa agar peserta didik secara aktif mengonstruksi konsep, hukum atau prinsip melalui tahapantahapan mengamati (untuk mengidentifikasi atau menemukan masalah), merumuskan masalah, mengajukan atau merumuskan hipotesis, mengumpulkan data dengan berbagai teknik, menganalisis data (menalar), menarik kesimpulan dan mengomunikasikan konsep, hukum atau prinsip yang di temukan.

Pembelajaran dengan pendekatan saintifik adalah proses pembelajaran yang dirancang sedemikian rupa agar peserta didik secara aktif mengkonstruksi konsep, hukum atau prinsip melalui tahapantahapan mengamati, merumuskan masalah, mengajukan atau merumuskan hipotesis, mengumpulkan data dengan berbagai teknik, menganalisis data, menarik kesimpulan dan mengkomunikasikan konsep, hukum atau prinsip yang ditemukan. Pada pembelajaran berbasis pendekatan ilmiah, retensi informasi dari guru sebesar lebih dari 90 persen setelah dua hari dan perolehan pemahman kontekstual sebesar 50-70 persen (Daryanto, 2014).

Pendekatan saintifik merupakan pendekatan yang berpusat kepada siswa. Majid (2014: 211) menyebutkan bahwa pendekatan saintifik dalam pembelajaran meliputi mengamati, menanya, mencoba, mengolah, menyajikan, menyimpulkan, dan mencipta. Beberapa prinsip pendekatan saintifik menurut Kurniasih dan Berlin (2014) dalam kegiatan pembelajaran adalah sebagai berikut: (1) pembelajaran berpusat pada siswa, (2) pembelajaran membentuk students self concept, (3) pembelajaran terhindar dari verbalisme,(4) pembelajaran memberikan kesempatan pada siswa untuk mengasimilasi dan mengakomodasi konsep, hukum, dan prinsip,(5) pembelajaran mendorong terjadinya peningkatan kemampuan berfikir siswa. (6) pembelajaran meningkatkan motivasi belajar siswa dan motivasi pengajar guru, (7) memberikan kesempatan kepada siswa untuk melatih kemampuan dalamkomunikasi, dan (8) adanya proses validasi terhadap konsep, hukum, dan prinsip yang dikonstruksi siswa dalam struktur kognitifnya

Tujuan dari penelitian ini adalah untuk meningkatkan hasilbelajar IPA siswa kelas V SDNegeri 164522 Tebing Tinggi melalui pendekatan saintifik.

\section{METODE PENELITIAN}

Dalam penelitian ini, peneliti menggunakan metode deskriptif. Metode deskriptif adalah suatu metode penelitian yang ditujukan untuk menggambarkan fenomenafenomena yang ada, yang berlangsung pada saat ini, atau saat yang lampau. Adapun subjek penelitian adalah siswa kelas V SD Negeri 164522 Tebing Tinggi dan 
sumber data yang digunakan adalah siswa dan teman sejawat.

Pada Penelitian tindakan kelas data yang dikumpulkan dapat berbentuk kuantitatif maupun kualitatif .Penelitian tindakan kelas tidak menggunakan uji statistik, tetapi dengan deskriptif. Data kuantitatif yang berupa nilai dianalisis dengan menggunakan analisis deskriptif komparatif yaiu membandingkan nilai tes kondisi awal, nilai tes setelah siklus I, dan II yaitu nilai dari hasil ulangan harian siswa kelas V pada siklus I dan II. Komponen pengajaran pendekatan saintifik yang sangat data kualitatif yang berupa observasi kegiatan guru, dan sisa serta data kuantitatif yangberupa nilai hasil ulangan harian siswa kelas V. Prosedur penelitian tindakan kelas iniada tahap perencanaan tindakan, pelaksanaan tindakan, pengamatan dan evaluasi, dan refleksi.

\section{Siklus I}

Pada siklus I guru membuat RPP dengan metode belajar pendekatan saintifik, menyusun materi pembelajaran, lembar pengamatan dan alat peraga/ sumber bacaan. Kegiatan yang merangsang siswa untuk aktif secara fisik maupunmental dalam penerapan pendekatan saintifik antara lain:

a. Mengamati. Melalui kegiatan pengamatan, siswa dapat mengamati lingkungan sekitar maupun gambar-gambar perubahan lingkungan fisik yang pernah terjadi maupun yang pernah siswa alami dalam kehidupan siswa.

b. Bertanya. Kegiatan menanya, melatih siswa untuk lebih berani mengungkapkan apa yang ada dalam fikirannya dan juga berani menyampaikan apa yang selama ini belum mereka ketahui.

c. Mengumpulkan informasi dan Eksperimen. Kegiatan mengumpulkan informasi dilakukan dengan membaca buku atau bacaan, mengamati gambar, dan tanya jawab dengan teman atau guru terkait apa yang ingin mereka ketahui.

d. Menganalisis. Tahap setelah eksperimen dan mengumpulkan informasi adalah kegiatan menganalisis.

e. Menyimpulkan. Siswa menyimpulkan hasil pengumpulan informasi maupun eksperimen dengan berdiskusi.

f. Mengkomunikasikan.

Pengetahuan baru yang didapat oleh siswa akan dipresentasikan oleh siswa di depan kelas kepada siswa lain.

\section{Siklus II}

Pada siklus II ini kegiatannya hampir sama dengan siklus I namun kekurangan yang terjadi pada siklus I diperbaiki pada siklus II. Hal-hal yang dianggap kurang pada siklus I diperbaiki pada siklus II.

Pengamatan dilakukan peneliti sendiri dan dibantu oleh pengamat. Pelaksanaan observasi dilakukan pada saat proses pembelajaran berlangsung dengan 
berpedoman pada lembar observasi yang telah dibuat oleh peneliti.

Data yang diperoleh pada lembar observasi, dianalisis secara lebih dalam dan tajam pada siklus ke dua ini. Kemudian dilakukan refleksiatau perenungan. Pelaksanaan refleksi merupakan hasil observasi/ pengamatan peneliti pada saat melakukan observasi di kelas dan lingkungan sekolah yang bertujuan untuk mengevaluasi hasil tindakan yang telah dilakukan yaitu dengan menerapkan pendekatan saintifik. Tahapan ini dilakukan secara berkesimbungan sehingga ditemukan hasil yang optimal.

Instrumen yang digunakan dalam penelitian ini adalah pedoman observasi, test hasil belajar dan kegiatan belajar mengajar. Data aktivitas belajar dan kendala yang dihadapi selama proses pembelajaran dikumpulkan melalui observasi Data hasil observasi dari hasilbelajar siswa setiap siklusnya, dianalisis dengan menggunakan teknik analisis statistik deskriptif.

Metode pengumpulan data penelitian ini adalah tertulis dan observasi. Penelitian ini dikatakan berhasil apabila siswa telah memperoleh nilai ketuntasan secara klasikal minimal $85 \%$ dari jumlah siswa dengan rumus sebagai berikut :

Persentase Ketuntasan klasikal $=$ Jumlah siswa yang tuntas $\times 100 \%$ Jumlah siswa yang mengikuti tes

\section{HASIL PENELITIAN DAN PEMBAHASAN}

Hasil data penelitian diuraikan berdasarkan siklus-siklus tindakan pembelajaran. Hasil data tersebut disesuaikan dengan masalah penelitian mencakup data perencanaan, dan proses pembelajaran. Hasil penelitian tindakan kelas menunjukkan bahwa pengamatan yang dilakukan oleh mitra kolaborasi dan peneliti pada aktivitas guru dan siswa melalui pendekatan saintifik pada mata pelajaran IPA kelas V SD Negeri 164522 Tebing Tinggi dapat dilihat pada Tabel 1 yaitu sebagai berikut:

\section{Tabel 1. Peningkatan Hasil Belajar} Melalui Pendekatan Saintifik

\begin{tabular}{c|c|c|c}
\hline \multirow{2}{*}{ Ket. } & \multicolumn{3}{|c}{ Peningkatan Hasil Belajar } \\
\cline { 2 - 4 } & $\begin{array}{c}\text { Pra } \\
\text { siklus }\end{array}$ & $\begin{array}{c}\text { Sikus } \\
\text { I }\end{array}$ & Siklus II \\
\hline $\begin{array}{c}\text { Nilai } \overline{\mathrm{x}} \\
\text { ulangan } \\
\text { harian }\end{array}$ & 68,5 & 71,4 & 72 \\
\hline $\begin{array}{c}\text { Jumlah } \\
\text { Siswa }\end{array}$ & 23 & 28 & 31 \\
\hline $\begin{array}{c}\text { Persen } \\
\text { Ketuntasan } \\
(\%)\end{array}$ & 65,71 & 80 & 88,57 \\
\hline
\end{tabular}

Hasil analisis pengamatan peneliti dari tindakan pra siklus, siklus I dan siklus II pada Tabel 1 terjadi peningkatan hasil belajar siswa. Hal ini dapat dilihat dengan peningkatan jumlah siswa dari 23 siswa yang tuntas belajar pada pra siklus menjadi 28 siswa yang tuntas belajar dengan pendekatan saintifik pada siswa kelas V SD Negeri 164522 Tebing Tinggi. Pada pra 
tindakan dari 23 siswa dalam satu kelas, terdapat 12siswa yang belum mencapai KKM.

Pembelajaran dengan penerapan pendekatan saintifik berpengaruh dalam meningkatkan keaktifan siswa dibandingkan dengan pembelajaran konvensional yang dilakukan guru. Hal ini ditandai dengan besarnya nilai rata-rata hasil observasi pada siklus I lebih besar dibanding pra siklus. Nilai ratarata kelas pembelajaran siklus Imenunjukkan peningkatan biladibanding dengan pra tindakan ke siklus I, yaitu dari 68,5 menjadi 71,4. Sementara persentase ketuntasan belajar siswa yang telah mencapai KKM dari pra tindakan meningkat dari $65,71 \%$ menjadi $80 \%$ pada siklus I.

Meskipun ketuntasan belajar pada siklus I belum mencapai yang diinginkan (Ketuntasan Belajar $\geq 85 \%$ ) namun sudah terjadi peningkatan dari pra siklus sebelumnya. Kegiatan menanya yang dilakukan siswa pada siklus I tidak hanya diarahkandari guru ke siswa, namun juga dari siswa ke guru. Hal ini terlihat dari kegiatan tanya jawab yang dilakukan siswa dan guru. Siswa tidak hanya menjawab pertanyaan guru, namun juga mengajukan pertanyaan kepada guru dan bertanya jawab dengan siswa yang lain. Hal tersebut menunjukkan bahwa pembelajaran dengan penerapan pendekatan saintifik berjalan sesuai dengan rencana. Siswa sebagian besar bersedia mengikuti kegiatan pembelajaran
IPA yang meliputi mengamati, menanya, mengumpulkan informasi/ eksperimen, menganalisis/ menyimpulkan, dan mengkomunikasikan.

Guru sudah mencoba memberi apersepsi dengan membawa gambar-gambar terkait materi untuk menarik perhatian siswa. Hanya saja ketika guru memberi materi dengan ceramah siswa kurang memperhatikan, banyak yang berbicara dengan temannya. Hal-hal yang dianggap kurang pada siklus I seperti perlu adanya dialog yang lebih santai agar siswa lebih terbuka dan tidak sungkan dalam mengeluarkan pendapat, memberikan motivasi pada siswa serta pengoptimalan belajar diperbaiki pada siklus II.

\section{Pembahasan}

Berdasarkan implementasi rancangan pada siklus II yang merupakan perbaikan dari tindakan siklus I diperoleh diperoleh peningkatan persentase ketuntasan belajar. Pada siklus II meningkat menjadi $88,57 \%$ dari $80 \%$. Hal ini berarti terjadi peningkatan $8,57 \%$ dari siklus I. Pada siklus II hanya 4 (empat) siswa yang belum memenuhi KKM atau $31(88,57 \%)$ siswa sudah tuntas belajar. Hal ini berarti ketuntasan belajar siswa sudah $\geq 85 \%$.

Siklus II ditujukan untuk memperbaiki kekurangan yang terjadi pada siklus I berdasarkan hasil refleksi siklus I. Dalam perbaikan ini diharapkan siswa 
menjadi lebih aktif dalam proses pembelajaran dan hasil belajar siswa dapat meningkat sesuai target yang akan dicapai. Pada siklus II ini ada peningkatan dan ketertarikan siswa untuk belajar IPA sehingga proses pembelajaran berlangsung baik dan menyenangkan. Seluruh proses pembelajaran dengan pendekatan saintifik melibatkan siswa secara langsung sehingga pembelajaran tidak lagi berpusat pada guru. Hal ini sesuai dengan pendapat Hosnan (2014) bahwa pendekatan saintifik adalah proses pembelajaran yang dirancang sedemikian rupa agar peserta didik secara aktif mengonstruksi konsep, hukum atau prinsip melalui tahapan-tahapan mengamati (untuk mengidentifikasi atau menemukan masalah), merumuskan masalah, mengajukan atau merumuskan hipotesis, mengumpulkan data dengan berbagai teknik, menganalisis data (menalar), menarik kesimpulan dan mengomunikasikan konsep, hukum atau prinsip yang di temukan.

Melalui pendekatan saintifik siswa merasa lebih cepat mengerti dalam memahami pelajaran IPA. Langkah-langkah pendekatan saintifik yang paling banyak memberikansumbangan terhadap meningkatnya keaktifan siswa baik secara fisik maupun mental adalah kegiatan mengumpulkan informasi dan eksperimen. Sedangkan yang paling sedikit memancing keaktifan siswa adalah kegiatan mengkomunikasikan. Dengan demikian, dapat disimpulkan bahwa pendekatan saintifik dalam pembelajaran IPA mempunyai pengaruh yang positif terhadap keaktifan siswa.

Maka dari itu pendekatan saintifik terbukti dapat meningkatkan hasil belajar siswa pada pelajaran IPA,terlihat dari hasil persentase ketuntasan belajar siswa yang mengalami peningkatan cukup signifikan mulai dari pre test, siklus I hingga siklus II.

\section{SIMPULAN}

Kesimpulan dari hasil penelitian diatas adalah penerapan pendekatan saintifik pada mata pelajaran IPAdi kelas V SD Negeri 164522 Tebing Tinggi berdampak positif dalam meningkatkan hasil belajar siswa setiap siklusnya. Hal tersebut dapat dilihat dari peningkatan persentase ketuntasan belajar siswa pada siklus I (80 \%), siklus II $(88,57 \%)$.

\section{DAFTAR RUJUKAN}

Daryanto. 2014. Pendekatan Pembelajaran Saintifik Kurikulum 2013. Yogyakarta: Gava Media.

Depdiknas. 2006. Kurikulum Tingkat Satuan Pendidikan Sekolah Dasar. Jakarta: BSNP.

Hamruni. 2012. Strategi

Pembelajaran. Yogyakarta: Insan Madani.

Hosnan. 2014. Pendekatan Saintifik dan Kontekstual dalam Pembelajaran Abad 21. Bogor: Ghalia Indonesia. 
Kurniasih, Imas \& Sani, Berlin.

2014. Implementasi Kurikulum

2013 Konsep \& Penerapan.

Surabaya: Kata Pena.

Majid, Abdul. 2014. Strategi

Pembelajaran. Bandung: PT

Remaja Rosdakarya.

Silbermen, Melvin. 2006. Active

Learning: 101 Cara Belajar

Siswa Aktif. Bandung:

Nusamedia.

Slameto. 2010. Belajar dan Faktor yang mempengaruhinya.

Jakarta: Rineka Cipta.

Usman, U. 2000. Menjadi Guru

Profesional. Bandung: PT.

Remaja Rosdakarya. 